\title{
PENDIDIKAN PEREMPUAN RIAU DARI MASA KE MASA
}

\author{
Wilaela \\ Universitas Padjajaran Bandung \\ wella_68@yahoo.com
}

\begin{abstract}
The existence of woman education instituation in Riau province has long history, far away before the existence of Riau as a province. The history can be divided into period of Dutch colonial, Japanese colonial till the period of independence. Every period has individuality differentiating from other period. Latifah School and of Madrasah Annisa in the empire of Siak in the period of colonization differ from Diniyah Putri Pasirpangaraian, YKWI and Diniyah Putri in Pekanbaru in the period of independence. However, there was a similiarity among the periods, that is the characteristic of woman education which had lifted the ability and role of woman as the primary and first educator and teacher, either in or out of the house, in the society, and in the school. The study also found that in each period, the woman education instituation in Riau has a relationship to Diniyyah Puteri Padang Panjang.
\end{abstract}

Kata Kunci: sejarah, pendidikan perempuan, ketrampilan, adat Melayu

\section{PENDAHULUAN}

Program pengentasan kemiskinan dan kebodohan di Propinsi Riau memerlukan dukungan dari berbagai komponen pembangunan di Riau. Dukungan dan keterlibatan aktif mereka dapat dibangun jika masyarakat Riau mengetahui sejarah perkembangan pendidikan di daerah mereka. Karena separuh lebih pelaku pembangunan $\mathrm{di}$ Indonesia, termasuk di Riau, adalah perempuan, maka pemberdayaan pendidikan perempuan Riau perlu ditingkatkan. Menggali sejarah pendidikan perempuan penting untuk kemudian menjadi dasar upaya memperbaiki pendidikan perempuan. Ada yang percaya bahwa pendidikan perempuan mampu mengeliminir dampak negatif dari pembangunan ekonomi dan masalah dalam dunia pembangunan. Paling tidak anggapan bahwa pendidikan perempuan sebagai salah satu jalan agar dapat menaikkan derajat bangsa yang sedang terjajah telah diyakini oleh sejumlah tokoh pendidikan perempuan di Indonesia pada masa awal abad ke-20.

Tulisan ini memaparkan sejumlah lembaga pendidikan perempuan yang ada di Riau sejak zaman penjajahan hingga era kemerdekaan. Selain berisi informasi tentang profil sekolah atau madrasah, kapan dimulai dan berakhir atau penutupannya, di mana didirikan, bagaimana latarbelakang dan perkembangannya, juga dikisahkan tentang rekam jejak orang-orang yang telah memberi andil dalam pendidikan kaum perempuan di Riau. Uraian yang tak kalah menarik dan penting adalah tentang mengapa lembaga-lembaga tersebut didirikan dan bagaimana keberadaan mereka dikaitkan dengan konteks zamannya. Metode sejarah digunakan dalam proses dari kegiatan heuristik (penemuan dan pengumpulan sumber) hingga penyusunannya 
menjadi suatu historiografi.

\section{PEMBAHASAN}

\section{Seputar Pendidikan Perempuan Riau}

Program education for all dan peningkatan kualitas pendidikan di Indonesia masih menjadi masalah besar sampai saat ini. Sistem pendidikan nasional kita ternyata belum mampu menjawab permasalahan tersebut, padahal pendidikan merupakan hak dasar setiap warganegara Indonesia yang dijamin dalam UUD 1945.

Program Pemerintah Propinsi Riau dengan isu strategis pengentasan kemiskinan dan kebodohan serta memajukan infrastruktur (K2I) mengisyaratkan dua fakta. Di satu sisi, dengan isu K2I, menunjukkan bahwa Pemerintah Riau memiliki komitmen untuk memperbaiki taraf kesejahteraan masyarakat Riau dan perhatian pada peningkatan kualitas pendidikan. Namun di sisi lain, isu tersebut jelas-jelas menunjukkan bagaimana kemiskinan di negeri yang kaya ini masih merupakan program tanpa ujung bagi pemerintah. Tingginya angka kemiskinan di Riau tentu berpengaruh terhadap tingkat dan mutu pendidikan, menyangkut usia sekolah, anak putus/tidak sekolah, dan minimnya sarana pendidikan. Di Riau sendiri, menurut hasil survey Pusat Data dan Informasi Perempuan Riau (Pusdatin Puanri) pada tahun 2006 diperkirakan terdapat 22,45\% penduduk miskin yang tentu saja berdampak pada pendidikan anak.

Keberhasilan pendidikan di Riau sebagai salah satu tolak ukur keberhasilan pembangunan masyarakat Riau mestinya dilihat dari sejauh mana pemerataan pendidikan bagi semua masyarakat Riau, di kota Pekanbaru atau di kabupaten/kota lainnya, di kalangan menengah keatas maupun pada keluarga miskin, dan bagi lakilaki maupun perempuan. Kenyataannya sampai saat ini, tingkat pendidikan masyarakat Riau pada umumnya dan perempuan pada khususnya memang masih mengkhawatirkan. Kekhawatiran ini kuat pula dirasakan oleh perempuan Riau yang tergabung dalam Pusat Studi Wanita (PSW) di perguruan tinggi, organisasi masyarakat, lembaga swadaya masyarakat ataupun forum pertemuan informal lainnya. Menurut Ashaludin Jalil, isu gender dalam rencana strategis pembangunan daerah cukup mengkhawatirkan karena institusi-institusi pemerintah dan parlemen daerah menempatkan gender lebih sebagai sebuah masalah alih-alih sebagai mainstream dalam perencanaan pembangunan. Konstruksi gender dalam pembangunan perencanaan daerah seperti itu serta merta menempatkan perempuan lebih sebagai sebuah patologi yang membutuhkan intervensi pemerintah untuk 'disembuhkan". Parahnya, bentuk-bentuk intervensi ini bukanlah sebuah intervensi yang affirmative action, melainkan intervensi yang tidak sejalan dengan kepentingan substansial perempuan.

Faktanya, anak putus sekolah, anak tidak sekolah, dan lain-lain isu, banyak dialami anak perempuan, ketimbang anak laki-laki. Isu strategis yang diterjemahkan dalam Program pendidikan Dinas Pendidikan Provinsi Riau di tahun 2006 sama sekali tidak mengindikasikan affirmative action di bidang pendidikan bagi perempuan untuk mempercepat pembedayaan perempuan Riau. Program sebagai solusi dalam mengatasi isu strategis pendidikan di Riau tidak berangkat dari perspektif kebutuhan 
perempuan.

Pendidikan bagi perempuan juga diyakini terkait erat dengan pengamalan nilai dan ajaran agama Islam yang mayoritas dianut oleh masyarakat Riau. Dengan pendidikan, umat menjadi terdidik, dan umat yang beragama dengan ilmu, lebih mulia daripada mereka yang beragama tanpa ilmu. Disamping tentu saja, bahwa perempuan (baca: ibu) adalah madrasah awal seorang manusia. Oleh karena itu, untuk mendapatkan sumber daya manusia yang cerdas meniscayakan ibunya yang seorang perempuan, harus cerdas pula. Jika sumber daya manusia suatu bangsa cerdas dan berkeadaban, maka negara bangsa tersebut akan maju. Kira-kira demikian pemahaman keagamaan masyarakat tentang pendidikan dan perempuan, sekalipun pada prakteknya tidak selalu dapat dipedomani mengingat kuatnya budaya patriarkhat yang menekankan dominasi laki-laki (bukan perempuan) di ranah publik.

Sejarah pendidikan perempuan di Riau, jika menyangkut lembaga pendidikan khusus untuk perempuan telah dimulai di Kerajaan Siak atas prakarsa permaisuri Sultan Syarif Kasim II, yaitu Tengku Agung. Bersama dengan sultan, ia mendirikan Latifah School (1927) sebagai sekolah ketrampilan dan disusul dua tahun berikutnya mendirikan Madrasah Annisa (1929), yaitu sekolah agama khusus perempuan di Kerajaan Siak. Untuk periode kolonial ini, sebuah lembaga pendidikan di Riau yang hampir tidak disinggung dalam berbagai tulisan tentang pendidikan perempuan di Riau adalah Diniyyah Putri Pasirpangaraian, sebuah sekolah agama yang didirikan oleh seorang murid Encik Rahmah El-Yunusiyah dari Diniyyah Putri Padangpanjang, yaitu Aisyah Umar. Madrasah ini menjadi saksi bagaimana keadaan perang mampu memperpuruk kondisi pendidikan di tanah air yang memang telah memprihatinkan. Sekolah Ketrampilan Perempuan Islam (SKPI) di bawah Yayasan Kesatuan Wanita Islam (YKWI) adalah lembaga pendidikan pertama yang didirikan di Pekanbaru pasca pengakuan kedaulatan (1953). Sebelumnya, perempuan-perempuan Pekanbaru juga menerima pendidikan agama melalui wirid pengajian yang dikelola oleh YKWI di bawah pimpinan Syamsidar Yahya dan kawan-kawannya. Salah seorang kawannya yaitu Chadijah Alie kemudian mendirikan Diniyyah Putri Pekanbaru yang masih tetap menyelenggarakan pendidikan pondok pesantren dan madrasah khusus perempuan hingga saat kini. Sekalipun kehadiran lembaga-lembaga tersebut berbeda masa, menariknya, ternyata semuanya memiliki keterkaitan dengan Diniyyah Putri Padangpanjang. Dapat dikatakan bahwa kajian tentang pendidikan perempuan di Riau secara tidak langsung terkait dengan Diniyyah Putri Padangpanjang dalam hal kepeloporan atau keperintisan, peran, dan popularitasnya sebagai lembaga pendidikan khusus perempuan di tanah air.

\section{Perempuan dan Budaya Melayu di Riau}

Kondisi perempuan dalam budaya Melayu termasuk di Riau pada sepertiga pertama abad ke-20 diliputi dengan masalah-masalah sosial terkait dengan adat seperti berkurung atau pemingitan anak gadis. Masalah perkawinan juga marak, seperti pernikahan anak-anak, kawin paksa, kawin lari, poligami, dan perceraian. Karya sastra sezaman dari Riau, seperti Kasih Ta' Terlarai (1931) dan Mencari Pencuri Anak Perawan (1932) karya Soeman Hs juga menyiratkan kisah tentang perempuan dan 
adat. Pro-kontra pendidikan bagi kaum perempuan juga banyak diberitakan di surat kabar lokal yang terbit di Padang, Medan, dan Batavia. Kondisi ini umumnya dialami juga oleh perempuan Indonesia di berbagai tempat, sehingga kemudian menjadi agenda dalam Kongres Perempuan Indonesia (1928) di Yogyakarta dan Kongres Perikatan Perempuan Indonesia (1929) di Jakarta.

Sekalipun memiliki banyak keterbatasan karena adat, perempuan Melayu menerima pendidikan agama sejak kecil hingga akil baligh. Anak perempuan belajar agama di rumah guru atau belajar mengaji Al-Qur'an dengan ibunya. Umumnya perempuan Melayu pandai baca tulis Arab-Melayu. Di kampung-kampung, masyarakat biasa mendengar sayup-sayup sampai suara gadis bersyair dan kaum ibu membaca hikayat. Perempuan yang masuk sekolah modern juga mulai banyak, tetapi banyak lagi yang tidak bersekolah. Kalau anak perempuan bersekolah, maka cukup sekolah rendah saja. Perempuan bersekolah di sekolah gouvernement seperti di HIS (Hollandsch Inlandsch School) masih menjadi perdebatan. Tidak hanya karena setelah sekolah kemudian ia akan kesulitan mendapatkan bidang pekerjaan yang sesuai lalu kembali ke dapur, tetapi juga karena tingkah-laku dan penampilan anak gadis yang bersekolah di HIS dipandang tidak patut menurut adat dan agama. Pembatasan pendidikan bagi anak perempuan tidak hanya dilakukan oleh orang tua, tetapi juga oleh masyarakat sekitarnya.

Dalam alam kemerdekaan sampai menjelang akhir abad ke-20, perempuan Riau masih memiliki berbagai keterbatasan sosial, budaya dan ekonomi, antara lain akibat pendidikan yang rendah. Angka partisipasi sekolah dan tamat sekolah perempuan Riau secara umum lebih rendah dari laki-laki. Tingkat melek huruf dan aksesibilitas media kaum perempuan Riau pun lebih rendah daripada laki-laki. Dengan pendidikan yang rendah, kaum perempuan lebih cepat masuk pasar kerja dan menikah, namun peran perempuan di bidang ekonomi, politik, dan lain-lain, masih tetap rendah sekalipun ada peningkatan.

\section{Pendidikan Agama}

Sekolah-sekolah partikelir (particulier) berupa lembaga kuttab banyak didirikan di Sumatera, termasuk di Riau pada masa kekuasaan Hindia Belanda. Sekalipun sebagian masih merupakan pendidikan tradisional, namun berkat lembaga pendidikan Islam ini anak-anak laki-laki dan perempuan bumiputera tetap melek bacatulis Arab dan Arab Melayu. Pendidikan tradisional inilah yang diistilahkan Azyumardi Azra (1999) sebagai pendidikan indigenous yang pada mulanya berlangsung di surau atau di rumah guru.

Adapun lembaga pendidikan modern adalah sekolah yang diperkenalkan oleh pemerintah Hindia Belanda. Sekolah Belanda yang ada di Riau hanya setingkat sekolah rendah, dari volksschool, Inlandsch School, hingga HIS, Schakel School, Vervolgschool, dan Hollandsch Chinesschool. HIS atau sekolah Melayu berbahasa Belanda (1915) di Siak Sri Indrapura merupakan satu dari dua HIS gouvernement di Riau pada waktu itu. Untuk dapat memasuki HIS ini tidak ada pembatasan seperti di Jawa yang hanya menerima anak kalangan bangsawan dan orang terkemuka. Pintu HIS Siak Sri Indrapura terbuka untuk siapa saja, tetapi tetap saja tidak sembarang 
orang bisa memasukinya. Di samping letak sekolah itu jauh, uang sekolahnya juga mahal. Kemampuan masyarakat umum untuk memasukinya memang terbatas. Menurut Brugmans dan Benda, Politik Etis memang tidak dijalankan dengan serius, tidak menjangkau seluruh anak bumiputera, dan tidak dengan dana yang cukup. Di Sumatera, kalangan bumiputera memandang pendidikan yang dijalankan oleh pemerintah tidak cukup merata dan tidak benar-benar untuk perubahan nasib mereka.

\section{Latifah School}

Tatkala Belanda semakin menancapkan kekuasaannya di Siak Sri Indrapura, Sultan ke-12, sultan terakhir kerajaan ini yaitu Sultan Syarif Kasim II mencoba menahan laju pengaruh Belanda dengan memberikan perhatian kepada pendidikan. Lembaga pendidikan yang didirikan oleh Sultan merupakan simbol penentangan dan ketidaksenangan Sultan kepada Belanda. Sultan mendirikan sekolah agama yaitu Madrasah Taufiqiyyah al Hasyimiyyah tingkat dasar (MI\&MTs) dan bersama permaisurinya, mendirikan Sultanah Latifah school, yaitu pendidikan khusus perempuan. Ide untuk memberikan pendidikan kepada kaum perempuan Siak merupakan pemikiran yang maju, mengingat pada waktu itu, di tahun 1920-an tidak satupun terdapat sekolah putri di Riau. Sebaliknya, di daerah-daerah lain di luar Kerajaan Siak, seperti di Medan, Langkat, Padangpanjang, Bukittinggi, Padang, telah berdiri sekolah khusus perempuan (meisjesschool).

Sumber lokal sezaman tentang pendidikan di Siak terbatas, jarang diberitakan, dan informasinya tercecer dibandingkan dengan daerah lain. Sesekali ada berita tentang pendidikan di Siak, biasanya bercerita tentang kepedulian sultan terhadap dunia pendidikan, sehingga dikenang rakyatnya sebagai sultan yang peduli pendidikan dan kemajuan. Sultan hendak memberlakukan wajib belajar (leerplicht) di Siak. Oleh karena itu, ia tidak mentolerir anak sekolah yang suka mangkir dan memilih menakik getah supaya mendapat uang dari perusahaan getah. Sultan dan Tengku Agung gemar mengunjungi sekolah-sekolah seraya bertanya jawab dengan murid-murid dan majelis guru, serta mengizinkan istananya dikunjungi oleh muridmurid. Sultan juga menyediakan sampan landschap untuk penyeberangan terutama bagi murid-murid yang tinggal di seberang Sungai Siak. Asrama (internaat) disediakan bagi murid sekolah yang berasal dari luar atau tidak tinggal di rumah famili di Siak Sri Indrapura. Beasiswa (steun) diberikan kepada mereka yang ingin melanjutkan pendidikan ke jenjang yang lebih tinggi di luar Siak.

Sejarah Latifah School di Kerajaan Siak terkait erat dengan riwayat hidup Tengku Agung (1896-1929) permaisuri Sultan Syarif Kasim II. Dari peninggalan berupa foto-foto, Tengku Agung digambar sebagai perempuan cantik dan anggun. Dari tutur lisan masyarakat Siak, ia dikisahkan berbudi pekertinya halus dan memiliki tutur kata yang lembut. Susur galurnya dari garis ayahnya, Tengku Agung berasal dari Siak dan dari sebelah ibu, Tengku Agung adalah kemenakan dari Sultan Langkat.

Kota Tanjungpura di Kerajaan Langkat sebagai kota kelahiran Tengku Agung, merupakan kota dengan pendidikan yang terus tumbuh dan berkembang dengan baik. Tengku Agung sering mendampingi sultan dalam kunjungan ke luar istana. Di antaranya, tatkala sultan pergi ke Medan menghadap residen Belanda, Tengku Agung 
turut serta. Medan adalah kota yang maju di Sumatera. Di sana, Tengku Agung mendapati bahwa perempuan telah memperoleh pendidikan. Bahkan mereka memiliki rumah sakit bernama Inlandsche Vrouwen Hospitaal dan perkumpulan seperti Keutamaan Istri.

Dapat dikatakan, kemajuan pendidikan perempuan di kota Tanjungpura, tempat kelahiran Tengku Agung dan di Medan, kota yang dikunjunginya, telah menginspirasi Tengku Agung untuk mendirikan sekolah bagi perempuan Siak. Terdapat perbedaan pendapat tentang tahun berdiri Latifah School. Leyds (1929) menyatakan pada tahun 1927. Pendapat lain, seperti Ahmad Yusuf (1992) menyebutkan tahun 1926, sementara dalam Sejarah Riau (1999) ditulis tahun 1928. Nama sekolah tersebut, Latifah School atau Sultanah Latifah School untuk pertama kali disebut secara jelas dalam $\mathrm{MvO}$ Controleur Siak, Kempe Valk (1931) sebagai volksschool spesial untuk gadis. Latifah School termasuk dalam group sekolah landschap, mendapat simpati dari kerajaan, dan sepenuhnya dibiayai oleh sultan. Nama Latifah School diambil dari nama permaisuri Tengku Agung yaitu, Syarifah Latifah. Umumnya buku-buku sejarah tentang Siak saat ini dan informan yang ditemui sepakat bahwa Latifah School didirikan atas ide prakarsa Tengku Agung yang mendapat dukungan penuh dari sultan. Mereka berpegang pada pemberian nama Sultanah Latifah School tersebut terkait dengan peran Tengku Agung atas sekolah tersebut. Ada dikatakan tetapi belum dapat dibuktikan bahwa sekolah ini disebut sekolah sultanah, karena status Tengku Agung adalah sultanah yang dapat menggantikan sultan jika sultan berhalangan. Sementara menurut OK Nizami Jamil, sultanah itu hanya merujuk kepada status Tengku Agung sebagai permaisuri, bukan sebagai pemimpin kerajaan yang sewaktu-waktu dapat mengganti sultan jika sultan berhalangan.

Latifah School merupakan sekolah khusus perempuan pertama di Riau dan kurikulum serta pengelolaannya berada dalam pengawasan Tengku Agung. Selain pengetahuan umum dan bahasa Belanda, di sekolah ini juga diajarkan keterampilan kerumahtanggaan (huishouden), keterampilan tangan (handwerken), dan kebersihan (hygiene). Pada tahun 1929, Leyds melaporkan Latifah School memiliki dua kelas, 50 murid, absen sekitar $2 \%$, dan satu orang guru perempuan. Dua tahun kemudian, Valk (1931) melaporkan bahwa jumlah muridnya 66 orang dengan tiga orang guru. Tidak disebutkan siapa guru-guru tersebut, namun dalam tulisan Ahmad Yusuf (1992) disebutkan bahwa mereka sengaja didatangkan dari luar Siak, sesuai dengan kebutuhan matapelajaran. Halimah Batang Taris dari Pematangsiantar mengajar Bahasa Belanda merangkap kepala sekolah, Encik Saejah dari Siak Sri Indrapura mengajar pelajaran menjahit, dan Zaidar dari Payakumbuh mengajar memasak. Disebutkan bahwa Latifah School dapat berkembang sampai lima kelas. Boleh dikatakan bahwa jumlah murid Latifah School cukup besar dan terdapat peningkatan jumlah murid dan guru pada lima tahun pertama keberadaannya.

Setelah laporan dua controleur Siak di atas, tidak diketahui secara tepat jumlah murid Latifah School pada tahun-tahun berikutnya. Laporan Controleur Siak, J Dijk (1935-1937), juga masih menyebutkan tentang meisjesvolksonderwijs di Siak, tetapi tanpa keterangan. Controleur Bengkalis, JP de Putter (1938), melaporkan 
perkembangan jumlah murid di landschap Siak pada setiap kwartal pertama dari tahun 1935 hingga 1938. Ada peningkatan jumlah murid baik laki-laki maupun perempuan. Laporan ini tidak menyebutkan secara spesifik sekolah mana saja yang termasuk dalam total jumlah murid tersebut, tetapi Ahmad Yusuf (1922) ada menyebutkan bahwa murid Latifah School pernah mencapai 100 orang. Bisa disimpulkan terjadi peningkatan anak perempuan di Siak yang bersekolah setelah lima tahun keberadaan Latifah School.

Kapan tepatnya Latifah School ditutup, sejauh ini belum ditemui sumber primer tertulis yang mendukungnya. Dari Sejarah Riau dan dari tutur lisan menyebutkan ketika terjadi pendudukan Jepang tahun 1942, Latifah School dialihkan sebagai sekolah rakyat.

\section{Madrasah Annisa}

Sultan Siak mendukung pendidikan perempuan yang memang merupakan hak perempuan untuk mendapatkannya. Menurutnya, pendidikan perempuan itu perlu asalkan tidak melalaikan pendidikan agama. Inilah salah satu alasan didirikan Madrasah Annisa (1929). Perkembangannya banyak dikaitkan dengan sultan dan Tengku Maharatu (lahir 1911), permaisuri sepeninggal Tengku Agung. Tengku Maharatu meningkatkan hubungan baik dengan Rahmah El-Yunusiyah (1900-1969), pendiri Diniyyah Putri Padangpanjang. Lembaga ini menurut Azra (2000) merupakan salah satu madrasah paling terkenal di Indonesia dan meskipun organisasi lokal, tetapi menurut Taufik Abdullah (1993) berdampak sosial yang besar. Selama tahun 1934 hingga 1941, guru-guru didatangkan dari Padangpanjang, sementara muridmurid terbaik Madrasah Annisa diberikan beasiswa untuk melanjutkan kesana. Sultan dan Tengku Maharatu pernah mengunjungi Diniyyah Putri dan sebaliknya, Encik Rahmah sering datang ke Siak Sri Indrapura, mengunjungi Madrasah Annisa untuk memberikan bimbingan dan melakukan pengawasan.

Pakaian para siswi Latifah School dan Madrasah Annisa terdiri dari baju kurung atau kebaya dengan selendang yang dikerudungkan di kepala. Keadaan ini dapat disaksikan dalam foto yang terpajang di dinding istana Asseraya Hasyimiah sekarang. Dari otobiografi saksi sejarah O.K.Nizami Jamil, sampai tahun 1950, Madrasah Annisa dan Madrasah Taufikiyah masih berdiri dan pada akhir tahun 1960an, keduanya diubah menjadi MTs Negeri Siak Sri Indrapura.

Peran Latifah School dan Madrasah Annisa adalah pada diseminasi kerajinan asli anak negeri. Kerajinan dimaksud adalah menenun dan menekat. Sejak abad ke-19, keterampilan tersebut dilakukan di dalam istana baru kemudian merembes ke luar istana. Belakangan murid-murid Latifah School dan Madrasah Annisa yang tinggal di internaat Istana Limas juga menenun-menekat. Murid-murid perempuan yang tidak tinggal di istana, turut serta membantu pengembangan kerajinan tersebut sebagaimana yang dialami oleh Encik Hasnah, yang pernah belajar menenun dari neneknya yang menjadi juru masak untuk istana. Khusus untuk Madrasah Annisa, alumninya ada yang menjadi mubalighat di tengah masyarakat.

\section{Diniyyah Putri Pasirpangaraian}


Di Pasirpangaraian tempat berkedudukan Bupati Rokan Hulu sekarang, salah seorang perempuan Riau alumni Diniyyah Putri Aisyah Umar dengan dukungan neneknya, Khadijah, dan masyarakat Pasir membuka sekolah yang diberi nama, Diniyyah Putri dan ia menjadi gurunya. Selain itu, ia juga memberikan kursus dasar bisa baca tulis kepada perempuan-perempuan muda yang telah berumah tangga. Kursus ini disebut sekolah menyosa, yang dimaksudkan menyesal kalau tidak sekolah. Istilah ini sama dengan yang dipakai sebelumnya oleh Rahmah Elyunusiyah tatkala mengajar kaum perempuan muda yang telah berumah tangga di Padangpanjang. Aisyah Umar juga mahir bertabligh untuk menyampaikan ajaran agama yang terkait dengan kaum perempuan sekaligus memperkenalkan sekolahnya.

Perjuangan dan pengaruh Aisyah Umar tersebut mengilhami sejumlah anak gadis di Pasirpangaraian untuk bersekolah lebih tinggi ke Diniyyah Putri Padangpanjang. Pada tahun 1950, ada tujuh gadis belia asal Pasirpangaraian yang melanjutkan sekolah ke Diniyyah Putri Padangpanjang. Mereka adalah Saudah, Roslaini Djadin, Roslaini Morah, Halimah HS, Nurmawan, Murbani, dan Rawiah. Perjalanan dari Pasirpangaraian dilakukan dengan berjalan kaki, sampai di Rao Pasaman baru dilanjutkan dengan mobil yang sering terpuruk lumpur ke Padangpanjang. Setelah tamat pada tahun 1957, Saudah, Roslaini Djadin, dan Roslaini Morah membuka kembali Diniyyah Putri Padangpanjang yang sempat tutup disebabkan agresi kedua. Banyak penduduk mengungsi termasuk Aisyah Umar yang kemudian meninggal pada tahun 1950. Akan tetapi, Diniyyah Putri ini tidak dapat bertahan lama, karena tidak lama kemudian, pada tahun 1958, pecah peristiwa PRRI yang menyebabkan masyarakat mengungsi meninggalkan Pasirpangaraian.

Belakangan, tanah sekolah tersebut diwakafkan ke Muhammadiyah. Aisyah Umar telah menjadi pengurus Muhammadiyah di Pasirpangaraian sejak kepulangannya dari Padangpanjang. Pada masa awal kemerdekaan, Aisyah Umar termasuk anggota Komite Nasional yang kemudian diubah menjadi dewan eksekutif dewan perwakilan kewedanaan di Rokan Kanan dan Rokan Kiri. Anggota lainnya adalah Soeman Hs. Aisyah Umar juga menjadi pengurus barisan perjuangan untuk kaum perempuan, bersama dengan Mahanum Yusuf, dan T. Mi'ah.

\section{Diniyyah Putri Pekanbaru}

Pendidikan madrasah di Indonesia dalam sejarahnya mengalami masa sulit yang panjang. Tidak hanya tekanan pada masa pemerintah kolonial, tetapi juga pada masa kemerdekaan. Pendidikan madrasah tidak dengan sendirinya dimasukkan dalam sistem pendidikan nasional dan hidup madrasah sebagai organisasi tidak memperoleh perhatian sepenuhnya dari pemerintah. Dalam konteks inilah perkembangan Diniyyah Putri Pekanbaru dapat ditempatkan. Tujuan pendidikannya menjadikan perempuan memiliki pengetahuan dan keterampilan sebagai ibu rumah tangga dan pendidik, tidak hanya di dalam rumah, tetapi juga di luar rumah.

Sekolah khusus perempuan ini didirikan pada tanggal 1 September 1965 atas prakarsa Chadijah Ali dibantu oleh Asmah Malin, Radenmas Oentoro Koesmarjo, dan Bakri Sulaiman. Chadijah Ali (1925-1986) lahir dan dibesarkan di daerah Senapelan sebagai wilayah asal-mula kota Pekanbaru. Ayahnya, H. Muhammad Ali berasal dari 
Pangkalan Kota Baru, Sumatera Barat, sebagai pionir yang mengembangkan banyak usaha di Pekanbaru. Antara tahun 1937-1942, Chadijah Ali tercatat sebagai bekas pelajar Diniyyah Putri Padangpanjang.

Pada awal Diniyyah Putri berdiri, Pekanbaru merupakan ibukota dari Propinsi Riau yang baru dibentuk. Pembangunan gedung sekolah Diniyyah Putri seiring dengan upaya pemerintah dalam menyediakan infrastruktur kota. Ketika peresmian gedung sekolah pada tahun 1968, Rahyah El-Yunusiyah hadir dan memberi sambutan. Sekalipun keterikatan dengan Diniyyah Putri Padangpanjang tidak secara administratif, tetapi kurikulum Diniyyah Putri Pekanbaru meniru kurikulum Diniyyah Putri Padangpanjang. Siswi yang berjumlah ratusan dilatih untuk mahir berpidato di depan khalayak, sebagai bekal untuk berperan di tengah masyarakat. Selain itu, sebagaimana tertuang di dalam bulletin Diniyyah Putri Pekanbaru, Shafa, singkatan dari Shaut al- Fatayat atau suara pemudi (1990), setiap siswi Diniyyah Putri Pekanbaru diharuskan memiliki kompetensi keterampilan keputrian seperti kerajinan tangan bordir, menyulam, membuat design baju, menjahit dan memasak. Murid juga diberikan ilmu untuk menjadi pendidik. Para murid Diniyyah Putri diasramakan dan berbagai pelajaran keterampilan teknis tersebut dapat dilatih secara bersama dalam kehidupan pondok. Guru-guru ada yang berasal dari Diniyyah Putri Padangpanjang dan juga ada dari tenaga pengajar di IAIN Susqa. Alumni Diniyyah Putri Pekanbaru dari tahun 70-an atau generasi awal sampai paroh pertama tahun 80-an adalah perempuan yang segera menonjol di tengah publik, turut berkiprah mengisi pembangunan, antara lain di bidang pendidikan.

Perhatian pemerintah kepada pembinaan madrasah mulai ditunjukkan setelah pengakuan pendidikan Islam sebagai subsistem pendidikan nasional pada tahun 1989. Perkembangan yang terjadi antara lain penyesuaian kurikulum, buku paket, dan sistem ujian akhir, telah membuat Diniyyah Putri juga melakukan penyesuaian. Sejak tahun 1990-an, keterampilan teknis yang diajarkan meningkat, sekalipun bukan lompatan. Sejumlah kegiatan ekskul diajarkan seperti, kursus penguasaan Bahasa Arab dan Inggris, muhadharah tiga bahasa (Indonesia, Arab, Inggris), seni rebana/nasyid, keterampilan menjahit, drumband, seni qira'at Al-Qur'an, kegiatan kepramukaan, Palang Merah Remaja, dan bimbingan paket ilmu mendidik dan praktek mengajar khusus kelas tiga MA. Jika dulu, Diniyyah Putri Pekanbaru memperkenalkan pendidikan berbasis keputrian yang terkait dengan peran jender perempuan, belakangan tujuan yayasan antara lain untuk menciptakan kemandirian siswa. Ini membuat ekskul menjahit tidak cukup, sehingga perlu dilengkapi dengan kursus komputer dan bahasa Inggris. Untuk beberapa alasan, program pondok pesantren sebagai program plus sejak tahun 1993 diterapkan dengan banyak kelonggaran. Program pondok dilaksanakan pada sore hari, setelah pembelajaran madrasah selesai. Belakangan, sejak tahun 2005, program pondok dilaksanakan dengan menambah satu jam di akhir pembelajaran madrasah.

Dengan demikian, perubahan yang terjadi merupakan proses pengembangan Diniyyah Putri Pekanbaru dalam merespon dinamika masyarakat. Perkembangan pendidikan Islam pada dasawarsa terakhir abad ke-20, tidak terlepas dari pertumbuhan kelas menengah Muslim yang membutuhkan sekolah unggulan. 
Mereka menginginkan anak mereka memiliki berbagai pengetahuan umum yang dibutuhkan pada zaman pembangunan, di samping tetap memiliki bekal pengetahuan agama yang memadai.

Di Pekanbaru, kecendrungan ini dapat diamati, diantaranya dengan berdirinya sejumlah sekolah elite Islam ko-edukasi, seperti Al-Shafa, Al-Ittihad, Al-Fityah dan AlAzhar Syifabudi. Jika sekolah unggulan tersebut didirikan untuk menangkap kecenderungan pasar Muslim kelas menengah ke atas, sebaliknya Diniyyah Putri tetap berpegang pada pendidikan yang mengutamakan kelas bawah. Pilihan ini bertolak dari kondisi riel di Riau namun ironik, sebagai salah satu propinsi terkaya di negeri ini, tetapi kemiskinan di desa-desa menjadi kehidupan nyata. Pertumbuhan madrasah di Riau pada tahun 2004 meningkat 15\% pertahun, namun sebagian besar murid madrasahnya berasal dari kalangan kurang mampu. Pendidikan yang rendah dan tingkat kemiskinan yang masih cukup tinggi membuat pemerintah Riau pada tahun 2003/2004 mencanangkan program K2I, yaitu pemberantasan Kemiskinan dan Kebodohan serta peningkatan Infrastruktur. Karena membaca keadaan ini agaknya Diniyyah Putri memilih tetap bertahan sebagai madrasah untuk kaum bawah. Selain itu, ketidaksiapan yayasan Diniyyah Putri mereposisi madrasah menjadi madrasah unggulan ditunjukkan oleh keterbatasan sumber daya dan kondisi saranaprasarananya.

\section{Peran Diniyyah Putri Padangpanjang}

Dalam buku 25 Tahun Diniyyah Putri (1939), Rahmah El-Yunusiyah menyatakan bahwa masyarakat dapat menjadi baik melalui rumah tangga, sebab rumah tangga adalah tiang masyarakat dan masyarakat tiang negara. Rahmah menginginkan setiap perempuan menjadi ibu yang baik dalam masyarakat dan mernjadi ibu guru yang baik di sekolah. Tujuan ini dapat dicapai kalau kaum perempuan mendapat pendidikan khusus dengan sistem pendidikan tersendiri. Hukum agama sangat erat sangkut pautnya dengan seluk-beluk keperempuanan. Begitu banyak masalah perempuan yang tidak dapat atau tidak mungkin dapat dibicarakan secara blakblakan dalam sistem pendidikan ko-edukasi. Rahmah berkesimpulan bahwa perlu ada sebuah perguruan khusus untuk anak-anak perempuan. Rahmah bercita-cita memperbaiki dan mengangkat derajat kaum perempuan melalui pendidikan modern berdasarkan prinsip agama. Derajat kaum perempuan tidak dapat diserahkan kepada orang lain untuk mengangkatnya, tetapi harus dilakukan oleh kaum perempuan sendiri.

Pengalaman pertama Rahmah mengajar di serambi masjid diikuti oleh tujuh puluh murid. Pada tahun 1927, untuk mempromosikan rencananya di bidang pendidikan dan untuk pembangunan kembali gedung sekolah yang runtuh akibat gempa bumi tahun 1926, Rahmah berkeliling ke berbagai daerah mencari donasi, seperti ke Medan sampai ke Semenanjung Malaya. Pada tahun 1930 mulailah dibuka kelas tujuh sebagai kelas tertinggi dari Almadrasatul Diniyyah. Maksud dibuka kelas ini adalah untuk memberi kesempatan kepada murid-murid Diniyyah Putri untuk mempelajari vak umum lebih luas dari yang telah diberikan. Akan tetapi rencana ini mendapat penolakan dari Rangkayo Rasuna Said, guru di madrasah tersebut. 
Menurutnya, kelas itu boleh didirikan asal memenuhi syarat yang diajukannya, yaitu bahwa pelajar yang memasuki kelas ini tidak perlu lagi menyambung pelajarannya yang lebih tinggi. Dengan kata lain kelas tujuh ini cukup mempunyai vak yang memuaskan saja. Sekalipun baik, tetapi tidak mungkin dijalankan, karena tidak mungkin membuka satu kelas yang cukup segala-galanya hingga tidak memerlukan lagi sambungan. Akhirnya kelas tujuh ini dijalankan dan disambut baik oleh pelajarpelajar.

Ketika pertama berdiri pada tahun 1923, Diniyyah Putri memiliki 10 sampai 20 murid, mempelajari Bahasa Arab dan sedikit ilmu agama. Akan tetapi, 15 tahun kemudian, pada tahun 1938, Diniyyah Putri telah menjadi satu perguruan putri yang terbesar dan terkenal di Indonesia yang telah mengirimkan murid-muridnya ke segala tempat, di dalam dan di luar Indonesia, dan telah memiliki cabang yang banyak. Diniyyah Putri memiliki tempat dalam Sejarah Indonesia dan setiap langkah perubahannya dipandang sebagai langkah kebangkitan putri Indonesia. Di usianya yang relatif masih muda, Diniyyah Putri telah memiliki sekolah setingkat volksschool untuk pelajaran menjahit, tenun, dan segala yang diperlukan untuk kaum perempuan. Kemudian ada sekolah khusus untuk pendidikan guru agama putri, yaitu Madrasah Muallimaat. Sekolah Umum juga ada untuk mempelajari pengetahuan umum dan murid dapat melanjutkan pendidikannya ke jenjang pendidikan yang lebih tinggi.

Dapat dikatakan bahwa upaya Diniyyah Putri Padangpanjang sangat membantu mempercepat dan memperluas wajib belajar (leerplich) bagi anak perempuan Indonesia. Setelah duapuluh lima tahun keberadaanya, jumlah anak perempuan bersekolah di Indonesia berdasarkan statistik tahun 1933/1934 belum setengah juta dari 17 juta lebih anak yang harus bersekolah. Anak Indonesia yang bersekolah memang masih rendah, lebih-lebih anak perempuan. Diniyyah School Putri telah mengusahakan percepatan pendidikan bagi kaum perempuan dan menyebarluaskannya ke berbagai daerah melalui alumni. Banyak alumni Diniyyah School Putri membangun sekolah di daerah masing-masing. Ada yang membuka sekolah khusus perempuan dan biasanya diberi nama sama, Diniyyah Putri atau nama lain, dan ada yang membuka sekolah ko-edukasi.

Berdasarkan kajian tentang lembaga pendidikan di Riau, terdapat hubungan baik langsung maupun tidak langsung pendidikan perempuan di Riau dengan Diniyyah Putri Padangpanjang. Hubungan ini telah dimulai sejak era pergerakan tatkala Madrasah Annisa didirikan hingga setelah Propinsi Riau berdiri. Hubungan tersebut tidak sebatas hubungan kerjasama dalam pengadaan guru dan pendidikan lanjutan bagi siswi seperti Madrasah Annisa, tetapi juga menyangkut sejarah dari keberadaan lembaga pendidikan perempuan di Riau. Yang terakhir ini misalnya hubungan historis antara Aisyah Umar pendiri Diniyyah Putri Pasirpangaraian, Chadijah Alie pendiri Diniyyah Putri Pekanbaru, Syamsidar Yahya pendiri YKWI dengan Diniyyah Putri Padangpanjang tempat dimana mereka mengenyam pendidikan. Selain itu, masih cukup banyak perempuan Riau yang berkiprah pada era sebelum kemerdekaan seperti Misbah Thaib dan setelah kemerdekaan merupakan alumni Diniyyah Putri Padangpanjang.

Beberapa diantara mereka yang dikenal di tengah masyarakat karena berbagai 
aktivitas mereka sebagai berikut. Asma Rahman, yang aktif di organisasi Wanita Islam dan mengelola beberapa yayasan, serta pendiri Yarsi Riau. Chadijah Ali, tokoh perempuan Riau yang mendirikan Diniyyah Putri Pekanbaru, berbagai lembaga pendidikan Islam dari Taman Kanak-Kanak sampai perguruan tinggi seperti UIR, dan mendirikan RSI Ibnu Sina. Maemanah Umar (lahir 1937) seorang tokoh di bidang pendidikan dan politik Riau, yang saat ini menjadi anggota DPD asal Propinsi Riau adalah alumni Diniyyah Putri Padang Panjang angkatan 1950, dan lulus tahun 1956. Siapapun di Riau mengenal Maimanah Umar, sumbangsihnya di bidang pendidikan bagi generasi muda Riau tidak diragukan lagi dan tapak rujuknya sebuah kompleks pendidikan Masmur yang terletak di jalan K.H. Ahmad Dahlan No. 96 Pekanbaru.

Dari daerah Tembilahan, Tembilahan Indragiri, Siti Ahmai Sulaiman (lahir 1941) yang juga didukung oleh ayahnya untuk bersekolah di KMI Diniyyah Putri Padangpanjang. Ia pernah menjadi anggota dewan disamping sebagai dosen di IAIN Sultan Syarif Kasim Pekanbaru. Selain itu terdapat Rukayyah Saleh dari Pekanbaru (lahir 1937) dan Asmah Salut dari Kampar yang mengabdi di dunia pendidikan. Yang terakhir ini tidak hanya berkiprah di kampus sebagai dosen di IAIN Sultan Syarif Kasim Riau, tetapi aktif juga di tengah masyarakat dan organisasi seperti Al-Hidayah. Sementara penyumbang atau wakaf kepada perguruan DP dari tahun 1965-1978 di antaranya dari Riau adalah Roslaini Ismail Suko, Maslamah Ali dan Maemanah Umar.

Adapun Roslaini Ismail Suko, seorang tokoh perempuan Riau yang banyak mengabdikan diri di bidang pergerakan dan organisasi perempuan, pada tahun 1950an lebih memilih Diniyyah Putri ketimbang memasuki SMP Pekanbaru. Bersama 6 orang kawannya dari Pasir pangaraian, Roslaini memilih Diniyyah Putri karena termotivasi oleh seorang tokoh perempuan di Pasir Pangaraiyan pada waktu itu, Aisyah Umar (tamat Diniyyah Putri tahun 1938). Disamping sebagai mubalighat, Aisyah Umar mendirikan sekolah khusus perempuan yaitu Diniyyah Putri Pasir Pangaraian dan membuka kursus untuk pemberantasan buta huruf yang dikenal dengan sekolah "menyosa" artinya menyesal tidak sekolah.

Keterikatan alumni dengan almamaternya tampak menonjol. Umumnya tersebut mendirikan sekolah yang dikelola mirip dengan Diniyyah Putri Padangpanjang. Apa yang dilakukan oleh Aisyah Umar, Chadijah Alie, dan Syamsidar Yahya dalam mendirikan dan mengelola sekolah meniru apa yang dilakukan guru mereka, Encik Rahmah dengan Diniyyah Putri Padangpanang. Tidak hanya sebatas itu, Syamsidar Yahya bahkan belajar dengan gurunya tersebut bagaimana cara menggalang dana untuk menyelenggarakan pendidikan. Ia melakukannya di Pekanbaru dengan menggalakkan beras genggam dari ibu-ibu peserta wirid pengajian untuk dapat menjalankan Diniyyah Awaliyah pada tahun 1952. Lain halnya dengan Chadijah Alie, ia melakukan pendekatan ke pemerintah. Hal ini dipermudah karena selain bertugas di pemerinahan yaitu di Djawatan Penerangan, Chadijah Alie juga aktif di organisasi partai seperti Muslimat Masyumi dan di Aisyiah. Maimanah Umar dalam mengelola lembaga pendidikan Masmur juga melakukan upaya pendekatan politik dan penggerakan keterlibatan masyarakat secara luas dalam pendidikan.

Dengan demikian dapat dikatakan bahwa Diniyyah Putri Padangpanjang melalui para alumninya telah berperan di dalam pengembangan pendidikan di Riau. 
Mereka mendirikan sekolah dan madrasah dan menjadi guru di lembaga yang mereka diriikan dan di tengah masyarakat. Aisyah Umar pada masa kolonial Belanda mendirikan sekolah dengan dukungan neneknya dan masyarakat Pasirpangaraian. Misbah Thaib di Siak Sri Indrapura telah menjadi guru dan perawat pada masa Jepang. Murid-murid Madrasah Annisa yang melanjutkan pendidikan di Diniyyah School Putri Padangpanjang juga menjadi guru sekembali mereka ke daerahnya. Bahkan ada sejumlah alumni Diniyyah Putri Padangpanjang yang menjadi guru tidak hanya di Siak dan Pekanbaru, tetapi juga di daerah-daerah lain di Riau. Pada masa kemerdekaan, nama-nama seperti yang telah disebutkan terdahulu, Chadijah Ali, Syamsidar Yahya, Maimanah Umar, Siti Ahmai Sulaiman, Rukaiyyah Saleh, Asmah Salut, adalah sedikit dari sekian alumni Diniyyah Putri Padangpanjang yang berjuang di bidang pendidikan di Riau. Roslaini Djadin atau yang lebih dikenal dengan nama Roslaini Ismail Suko, mewakili mereka yang mengabdikan diri secara aktif untuk meningkatkan pendidikan masyarakat Riau melalui pengajian-pengajian BKMT.

\section{SIMPULAN}

Lembaga pendidikan perempuan di Riau telah tumbuh sejak masa penjajahan hingga masa kemerdekaan. Dalam era pemerintahan kolonial Belanda, Tengku Agung yang berasal dari kalangan elite Istana Siak mendirikan sekolah ketrampilan Latifah School (1927) dan kemudian Madrasah Annisa (1929)_ sebagai sekolah agama yang melengkapi Latifah School_ dan menjalin hubungan dengan Diniyyah Putri Padangpanjang. Di Pasirpangaraian, Aisyah Umar, seorang alumni Diniyyah Putri Padangpanjang dengan bantuan neneknya dan masyarakat sekitarnya membuka sekolah khusus perempuan yang diberi nama Diniyyah Putri (1938). Keadaan perang telah membuat sekolah ini buka tutup. Keadaan perang pada masa Jepang memaksa guru turun ke sawah dan murid-murid mengungsi. Tidak ada informasi tentang bagaimana nasib sekolah tersebut pada masa perang pisik. Akan tetapi, peristiwa PRRI pada tahun 1957-1958 telah membuat masyarakat kembali mengungsi dan menutup sekolah.

Dalam alam kemerdekaan pasca pengakuan kedaulatan, Syamsidar Yahya istri seorang pejabat di Kampar menyelenggarakan wirid pengajian kaum ibu di Pekanbaru. Pengajian ini diikuti oleh lebih dari 300 orang dan dilakukan secara berkala setiap Jumat. Bersama teman-temannya, ia mendirikan Madrasah Awaliyah (1952) dan SKPI (1953) sebagai sekolah ketrampilan pertama di Pekanbaru. Chadijah Ali puteri pengusaha sukses di Pekanbaru dan alumnus Diniyyah Putri Padangpanjang ini mendirikan Diniyyah Putri di Pekanbaru (1965). Maimanah Umar juga mendirikan sekolah dalam berbagai jenjang di Pekanbaru, baik umum maupun agama, tetapi bersifat ko-edukasi. Sejumlah alumni lainnya seperti Rukaiyyah Saleh, Siti Ahmai Sulaiman, dan Asmah Salut menjadi tenaga pendidik di perguruan tinggi-perguran tinggi yang baru dibuka pada awal tahun 1970-an.

Kurikulum sekolah maupun madrasah khusus perempuan yang didirikan sebelum dan sesudah kemerdekaan di Riau memiliki sejumlah persamaan. Muridmurid diajarkan pengetahuan dan keterampilan keputrian, seperti memasak, mengurus rumah tangga, perawatan, kebersihan, dan ketrampilan tangan. Mereka 
disiapkan menjadi perempuan yang trampil sebagai istri dan ibu yang baik. Mereka harus bisa membina keluarga dengan baik dan terampil mengurus dan mendidik anak-anak mereka. Tidak hanya itu, murid-murid Latifah School dan Madrasah Annisa berperan dalam diseminasi ketrampilan tenun Siak.

Inti pendidikan perempuan sebagai pendidikan ketrampilan ini juga masih berlanjut setelah kemerdekaan. Kurikulum Diniyyah Putri Pekanbaru dan SKPI YKWI menunjukkan kecenderungan tersebut. Pendidikan ketrampilan masih dibutuhkan karena peran perempuan sebagai guru baik di dalam rumah maupun di luar rumah menjadi tujuan pendidikan. Perempuan sebagai guru di luar rumah diperlukan mengingat kondisi Pekanbaru khususnya dan Riau sebagai propinsi yang baru terbentuk dalam keadaan membangun dan membutuhkan peran serta masyarakat, perempuan dan laki-laki. Pengaruh ideologi ibuisme dan gender and development (GAD) yang dikembangkan pemerintah Orde Baru juga turut memantapkan pelaksanaan pendidikan ketrampilan di lembaga pendidikan khusus perempuan di Riau. Peran perempuan sebagai guru ini kadang berkembang mengikuti kondisi zaman. Mereka juga turut berjuang di masa perang dan memasuki organisasi dan partai pada awal kemerdekaan. Perkembagan dan perubahan masyarakat yang cepat karena perkembangan teknologi komunikasi dan informasi turut mengelaborasi kurikulum pada lembaga pendidikan perempuan. Diniyyah Putri Pekanbaru mulai tahun 1993 memperkenalkan ketrampilan komputer, karena ketrampilan memasak dan menjahit dipandang tidak memadai lagi bagi murid-muridnya.

Persamaan dari latarbelakang tokoh-tokoh pendidikan perempuan di Riau adalah berasal dari latarbelakang keluarga yang cukup menonjol di tengah masyarakat sekitarnya. Tengku Agung dan Tengku Maharatu bahkan berasal dari kalangan bangsawan. Mereka bersaudara dan menjadi permaisuri dari sultan terakhir Kerajaan Siak. Keinginan kuat mereka untuk memberikan pendidikan bagi kaum perempuan didukung sepenuhnya oleh Sultan Syarif Kasim II. Syamsidar Yahya adalah istri seorang patih Kabupaten Kampar yang kemudian menjadi bupati yang berkedudukan di Pekanbaru. Suaminya sangat mendukung usaha Syamsidar untuk mendidik kaum perempuan dan anak di Pekanbaru; bahkan menjadi penasehat dalam YKWI. Chadijah Ali berasal dari keluarga pionir dan terpandang di Pekanbaru. Perjuangannya di bidang pendidikan perempuan didukung sepenuhnya oleh orangtuanya dan suaminya. 